\title{
SiM
}

\section{History of University of California Rangeland Extension, Research, and Teaching}

\author{
By Melvin R. George and W. James Clawson
}

\section{On the Ground}

- The Agricultural Extension Service at the University of California (UC) was established in Humboldt County in 1913 preceding the nationwide establishment of the extension service in 1914.

- Improving rangelands by controlling weeds and brush, seeding, fertilization, and grazing management has been a continuing theme of research by UC since the late 1800 s.

- Restoration of annual-dominated grasslands with native perennials has been a recurring research theme that continues to challenge grassland researchers.

- The complexity of research questions and education programs increased when environmental issues including grazing effects on riparian areas, oak regeneration, wildlife habitat, and water quality began to influence range research and extension programs in the 1980 s.

- A more diversified range extension audience evolved with the increase in small farms and ranches and diversification of agency staff in response to affirmative action.

Keywords: University of California, Cooperative Extension, Agricultural Experiment Station, land grant, history.

Rangelands 36(5):18-24

DOI: 10.2111/Rangelands-D-14-00018.1

(C) 2014 The Society for Range Management

I $\mathrm{n}$ this historical overview, we chronicle the programs, people, facilities, and accomplishments that have contributed significantly to the success of rangeland extension, research, and teaching in the University of California (UC).

\section{The Early Years}

In 1868 UC, located in Berkeley, was chartered as California's land-grant university with the College of Agriculture being the first department. In 1875 the UC Agricultural Experiment Station, authorized by the Hatch Act, was established. In 1901 the Animal Science Division was started at UC Berkeley, followed by the Agronomy Division in 1904. In 1906 the University Farm was purchased in Davis. By 1909 the Animal Science and Agronomy divisions moved from Berkeley to Davis. The first students at Davis were enrolled in 1908 for short courses that emphasized technical training. In 1922 Arthur W. Sampson joined UC Berkeley as a lecturer in the School of Forestry and as the first "range" faculty.

In 1915 California established the Agricultural Extension Service in response to the passage of the Smith-Lever Act in 1914, and authorized the County Boards of Supervisors to expend funds to support county extension offices and staff. The first Cooperative Extension director, B. H. Crocheron, required that an organized agriculture group be established in the county before a farm advisor (county agent) would be placed there. ${ }^{1-3}$ In 1913 Humboldt County formed the first county farm bureau and established the first extension office in California, followed by Yolo, San Joaquin, and San Diego counties. In 1919 the California Farm Bureau Federation was formed and took over the establishment of the county farm bureaus. More than 150 extension specialists and farm advisors have conducted range research and extension programs throughout California since 1913.

Improving rangelands by controlling weeds and brush, seeding, fertilization and grazing management has been a continuing theme of research by UC since the late 1800s. In 1878 Dr Eugene W. Hilgard, Professor of Agriculture and Agricultural Chemistry, and Dr Edward J. Wickson, Professor of Horticulture in the College of Agriculture at UC Berkeley, received seeds of a bunchgrass, smilograss (Oryzopsis milliacea), from an experimental grass garden in New Zealand. In 1879-1880 they sent seed of this Asian native grass to farmers for range trials in several parts of California. ${ }^{4}$ 
In 1912 Dr P. B. Kennedy came to the UC Berkeley Division of Agronomy and initiated trial plots of native and exotic legumes and grasses throughout the state. During this time Dr Kennedy introduced hardinggrass (Phalaris tuberosa) from Australia and it is now widespread in California. While these early programs were small they were the forerunners of longer-term well-organized range improvement investigations.

\section{Brush Management and Range Improvement Programs}

In 1932 the UC College of Agriculture began to investigate ways to improve brush ranges. ${ }^{5}$ Investigations were started and information developed about vegetation change following fire and the controversial problems of runoff and erosion. These early studies included small watershed studies by F. J. Veihmeyer in several counties (Fig. 1). After World War II agricultural research in California accelerated, including on rangelands. The use of fire to control woody vegetation was an important part of UC investigations, but then, as now, there were conflicting views within the university and between agencies about the use of prescribed burning. Eventually these differences were overcome, resulting in a joint agreement on the role of UC and California Department of Forestry (CDF) that led to implementation of a range improvement burning program at the state level in 1945. In 1946 the State Board of Forestry established the Range Improvement Advisory Committee, now known as the Range Management Advisory Committee, to improve relations with ranchers. In 1951 this committee representing livestock and forestry associations, agencies, and UC recommended a coordinated brush range improvement program with local organizations to implement the program. In 1953 the plan was approved by the UC College of Agriculture, the Range Improvement Advisory Committee, and finally by the Board of Forestry. Agricultural Extension, UC College of Agriculture, and $\mathrm{CDF}$ were charged with assisting in the development of effective local organizations that became known as Range Improvement Associations. Initially the program was patterned after the successful Madera County Controlled Burning Program. In 1964 Les Berry, Range Improvement Extension Specialist, reported that 58 farm advisors and 16 extension specialists were actively engaged in some phase of the Range Improvement Program.

In 1947 CDF initiated range improvement field studies in several counties in cooperation with the Agricultural Extension Service and Agricultural Experiment Station. In 1950 the UC College of Agriculture initiated a series of brush range improvement demonstrations funded by the state legislature. This range demonstration project was conducted by personnel from the UC Davis Agronomy Department and the School of Forestry at UC Berkeley, including Harold Biswell who became known worldwide for his knowledge of prescribed burning.

In July 1938 an extensive series of grass and legume variety trials that eventually included 240 nurseries and broad-

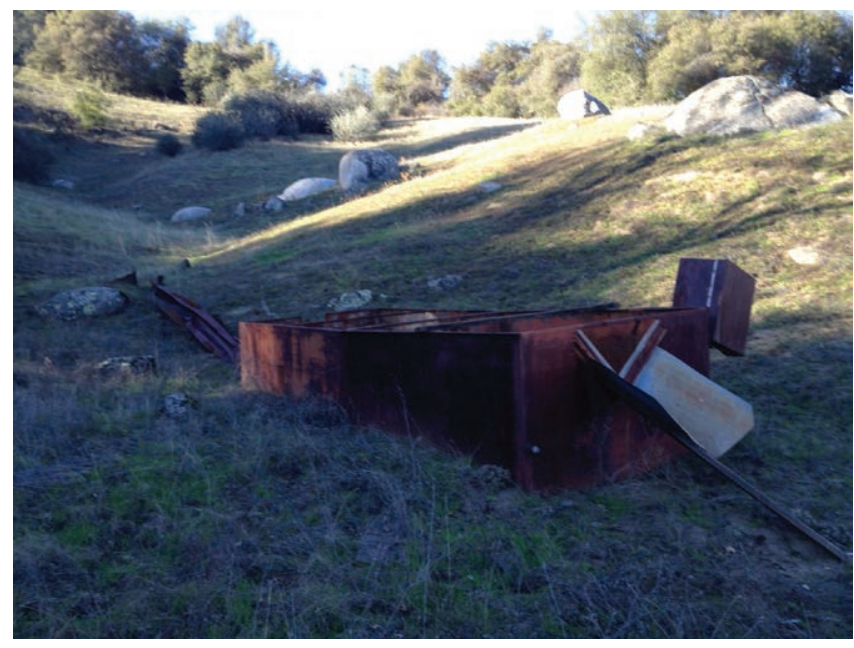

Figure 1. Remnant Veihmeyer flume near Ahwahnee, Madera County, California (taken December 2012).

cast plots in 40 counties (Fig. 2) was implemented by the Agronomy Department. In 1940 the department hired Dr R. Merton Love, who took leadership of these statewide trials and addressed key issues in rangeland management, including rangeland forage production and quality and grazing management practices that were compatible with these new plant materials.

Included in this initial testing program were many grasses and legumes from Australia, which would play a prominent role in range reseeding recommendations that resulted from this and later programs. After 8 years of testing, bur clover (Medicago hispida), introduced into the state during the mission period, was found to be a promising species for parts of the Sacramento Valley and Sierra foothills. Subterranean clover (Trifolium subterraneum) also looked good in some plots in those areas and also along the North Coast. Conspicuously absent from the initial list was rose clover (Trifolium hirtum). In the 1940s Dr Love introduced rose clover, which by the 1960s was widely naturalized to California. ${ }^{6}$

Of the 200 forage varieties included in trials from 1937 to 1945, 34 were native perennials. By 1945, it was evident that few native perennials were widely adapted. During this program purple needlegrass (Stipa pulchra) and nodding needlegrass (Stipa cernua) lines were selected from test plots at UC Davis and foundation seed was developed from a blend of 12 superior strains of each of these native grasses. ${ }^{4}$ Restoration of native perennials into California's annual-dominated rangelands is a recurring objective that remains unfulfilled unless the site allows for normal crop production practices including tillage and weed control. Exotic perennial grasses were also included to extend the green-forage season and maintain higher forage quality. By the 1960s only nonnative perennial grasses (hardingrass, smilo, summer-dormant orchard grass [Dactylis glomerata], and veldtgrass [Ehrbarta calycina]) were recommended. In 1945, Burle Jones and Dr Love authored Extension Circular 129 Improving California Ranges and in 1947 they authored UC Circular 371 Improving California 


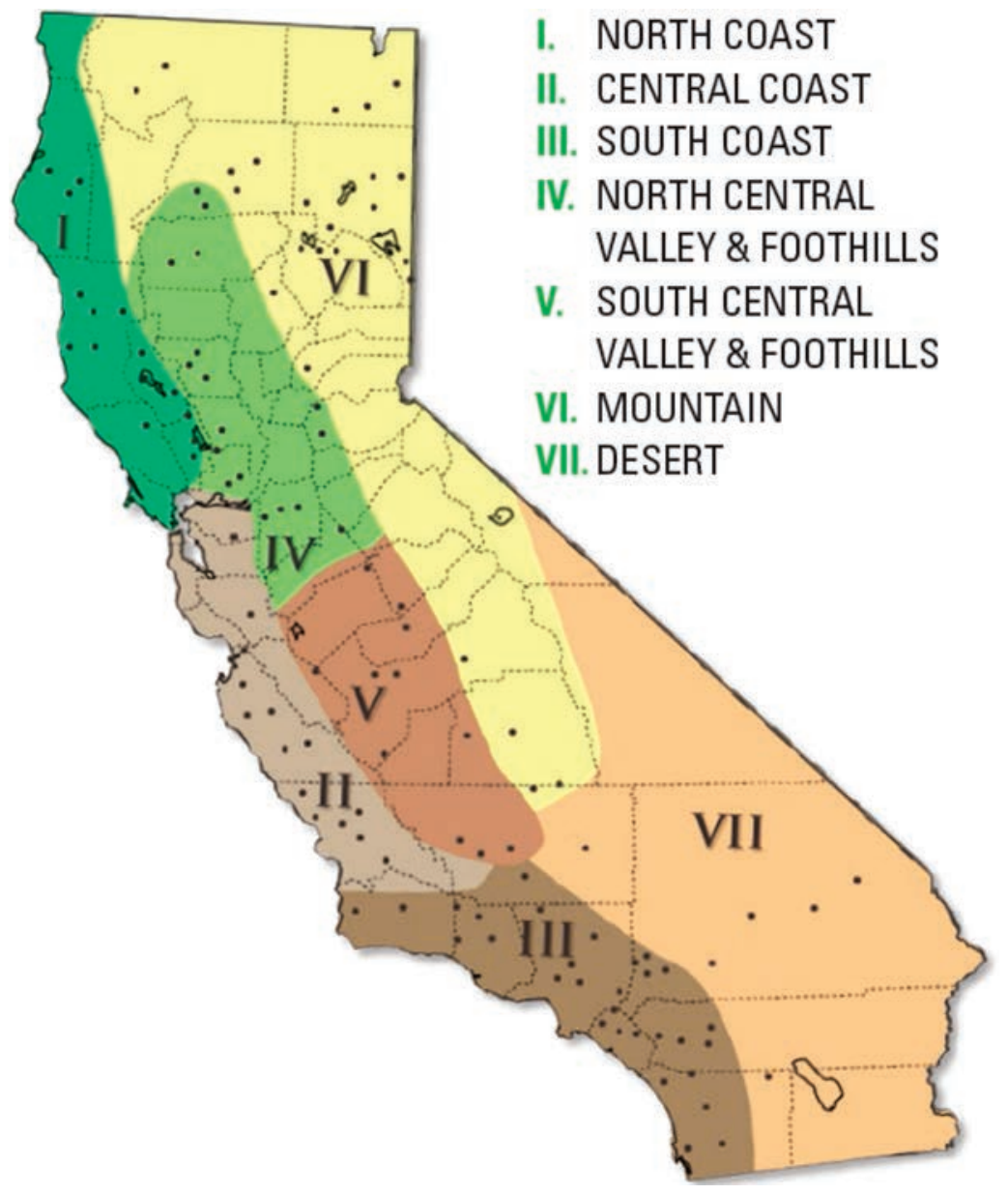

Figure 2. Climatic regions and locations of range nurseries and broadcast plots.

Brush Ranges. ${ }^{6,7}$ Both of these publications were the result of these statewide tests, observations, and interviews of stockmen.

Eventually the grass and legume testing program was taken over by the Agricultural Extension Service in collaboration with the Agricultural Experiment Station. ${ }^{8,9}$ Extension specialists in the Agronomy and Range Science Department led this program and conducted county trials with farm advisors throughout much of California. Several varieties of subterranean clover, rose clover, crimson clover (Trifolium incarnatum), and bur clover made their way into county seeding recommendations as a result of these county trials. This program worked closely with the seed industry and the USDA Soil Conservation Service (SCS), now known as the Natural Resources Conservation Service (NRCS). Legume inoculation with specific Rbizobium strains was a research focus starting in the 1960s that led to specific Rbizobium strains that were coated on the legume seeds prior to planting. ${ }^{10}$

While most of the focus was on plant materials for California's Mediterranean-type climate, rangeland tests by Bud Kay found several wheatgrasses (Agropyron spp.) and wildryes (Elymus spp.) to be adapted to the intermountain counties. ${ }^{11}$ Bud Kay and his collaborators also conducted germination and establishment studies on about 20 desert plants as part of their efforts to revegetate the second Los Angeles Aqueduct, which traversed more than 100 miles of the Mojave Desert from Owens Valley to Los Angeles. ${ }^{12}$

Starting in the 1940s scientists in the Division of Agronomy found that annual legumes responded to application of sulfur and/or phosphorus. In the 1950s UC Davis scientists reported production increases from nitrogen fertilizers when they were applied with phosphorus and/or sulfur. In the 1950s and 1960s county test plots and grazing trials led by Bill Martin (Extension Soil Specialist) and Les Berry (Extension Range Specialist) found that addition of nitrogen increased forage and animal production per acre but usually required sulfur and/or phosphorous along with the nitrogen. Beginning in the 1960s Dr Milton Jones, a soil fertility specialist at UC Hopland Field Station (now known as the UC Hopland Research and Extension Center [HREC]) began to study soil fertility and plant nutrition on rangelands. He conducted extensive studies of legume responses to phosphorus, sulfur, and other nutrients, and grass responses to nitrogen, phosphorus, and sulfur. He also conducted nutrient cycling studies, publishing a review of biogeochemical cycling in the annual grasslands. ${ }^{13}$ 
In 1947, one of the first successes in biological control in the world was started with the introduction of the Klamath weed beetle (Chrysolina quadrigemina) on the North Coast by the UC Division of Biological Control. Klamath weed (Hypericum perforatum) was, and still is, an important plant that is toxic to grazing livestock. The release of the beetle was very successful at suppressing Klamath weed and keeping it in check.

Agricultural Experiment Station and Extension Service researchers in agronomy and botany have investigated the biology and control of several rangeland weeds. Beginning in the 1940s medusahead control was the focus of research with studies that investigated palatability and control methods including burning and grazing. Yellow starthistle (Centaurea solstitialis) control has also been the focus of attention over the years and goatgrass (Aegilops triuncialis) control has also been investigated, especially in recent years, when it invaded millions of acres of foothill rangeland. ${ }^{14-16}$

As forestry and range research progressed it became important to know the capability of the land to support silviculture and range improvement practices. In 1947 the California Soil-Vegetation Survey program was started with CDF as the lead agency and collaboration from UC, SCS, and the USDA Forest Service Pacific Southwest Forest and Range Experiment Station. This survey covered the forests and rangelands (uplands) and the SCS Soil Survey focused on farmland.

\section{Research Stations}

In 1934 the USDA Forest Service established the San Joaquin Experimental Range (SJER) in Madera County with UC as a partner in beef cattle and zoological research, while the USDA Forest Service conducted range research. A variety of grazing, animal husbandry, range improvement (fertilization, reseeding, brush control, etc.), wildlife habitat, botanical, and zoological studies have been conducted at SJER. The UC Animal Husbandry Department placed an experimental beef cattle herd on the station to study what was needed to have a productive year-round commercial cattle operation in the foothills. Probably the most important cattle management information developed and used was the need for supplemental feed for the cow herd in the fall and early winter and that a "moderate" level of grazing was the most productive and economical. Studies at SJER led to a better understanding of California's annual rangelands and their use by livestock. In $1951 \mathrm{~J}$. R. Bentley and M. W. Talbot dissected the forage year into the inadequate green season, adequate green season, dry season, and dry leached season in recognition of the variability and nutritional value of range forage through the year. ${ }^{17}$ These designations are still used and taught to range managers today.

Recognizing the need for a permanent sheep production and range research station, UC established the 4,637-acre Hopland Field Station, now known as HREC on 1 July 1951 in Mendocino County. Al Murphy was director of the sta- tion from 1951 to 1986 . Initially the site of sheep production and brush control studies, HREC would become the site of extensive studies of predator control, range seeding and fertilization, oak woodland ecology and management, habitat management, and, most recently, watershed and water quality research. ${ }^{18}$

The UC Sierra Foothill Field Station (now known as the UC Sierra Foothill Research and Extension Center), in Yuba County, was acquired on 1 June 1960. The station has been the site of research, teaching, and extension projects in such areas as beef cattle production and health, oak woodland ecology and management, rangeland improvement practices, weed control, animal behavior, grazing management, watersheds and water quality, and, most recently, ecosystem services (Fig. 3)..$^{19,20}$

\section{Undergraduate and Graduate Education}

Range management education began with the hiring of $\mathrm{Dr}$ Arthur Sampson as the first range faculty at UC Berkeley in 1922. Professor Sampson's association with UC began with a lectureship, but in 1923 he was promoted to Associate Professor, in 1940 to Professor, and upon retirement in 1951 he was granted Emeritus status. He organized and strengthened the program of graduate study in forestry, and his four textbooks on range management plus many research publications have had far-reaching influence. ${ }^{21}$

Alan Beetle was an early researcher with interests in botany and rangelands. He received his $\mathrm{PhD}$ from UC Berkeley and was an agronomist in the Botany Department from 1940 to 1946. Dr Beetle was on the faculty of the University of Wyoming from 1946 to 1978 and was instrumental in starting the Department of Rangeland Ecology and Watershed Management. Dr Harold Biswell was appointed to the faculty of the School of Forestry in 1947, and he retired in 1973. He became a preeminent researcher, teacher, and advocate of fire ecology and management. His pioneering work was a major factor in developing new policies of controlled or prescribed burning. Dr Arnold Schultz joined the faculty at

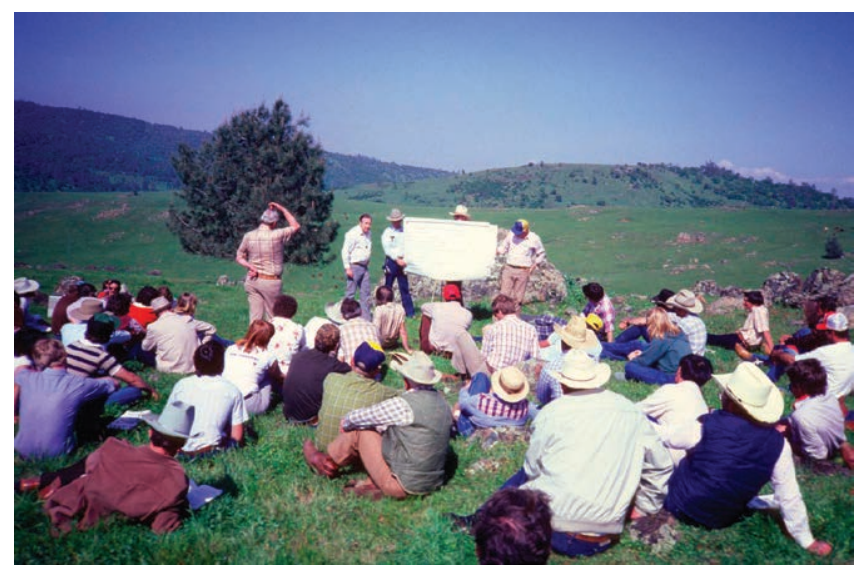

Figure 3. A field day on Forbes Hill at the Sierra Foothill Research and Extension Center in the 1980s. 
UC Berkeley in 1949. His early research career focused on prescribed brushland and forest burning, quantitative ecology methods, and tundra and desert ecology. Dr Schultz received the College of Natural Resources Teaching Award in 1991 and the University Teaching Award in 1992.

Dr Harold Heady was a range management ecologist at UC Berkeley from 1951 to 1984 . When Harold arrived at Berkeley in 1951 the university had just purchased the Hopland Field Station and was also expanding range management on the Davis campus. This led to many productive research collaborations and years of joint teaching on both the Berkeley and Davis campuses.

Dr Love joined the UC Davis faculty in 1940. He developed a distinguished career of research, teaching, extension, and public service and served as chairman of the Department of Agronomy from 1959 to 1970. A satellite program of the UC Davis Agronomy Department was established at UC Riverside in 1964 and staffed by Dr Cy McKell, as a department vice-chair, and faculty Joe Gooden, Vic Youngman, and Bill Isom. In 1968 the satellite program became the Plant Science Department at UC Riverside. In recognition of the importance of range science in the UC Davis Agronomy Department research, extension and teaching activities the department was renamed the Agronomy and Range Science Department in 1968. This name endured until a major consolidation of several departments in the late 1990s into the Plant Sciences Department.

The UC Berkeley-UC Davis joint major in rangeland management was first offered in 1953. Dr Sampson, along with recent faculty additions, Drs Heady and Biswell from the UC Berkeley School of Forestry; Drs Love, Horton Laude, and Bill Williams from the UC Davis Agronomy Department; and Dr William Weir from the UC Davis Animal Science Department were faculty for the program. Dr Shultz at UC Berkeley and Beecher Crampton at UC Davis also taught in this joint program. Several graduate students also participated in teaching. In addition to range science courses, the curriculum included courses in forestry, soils, agronomy, taxonomy, and animal science, and a good breadth in the general sciences and liberal studies (J. Stechman, personal communication, June 2012).

\section{Managing Ecosystems and Impacts}

By the 1980s environmental issues, including grazing effects on riparian areas, oak regeneration, wildlife habitat, and water quality, began to influence range research and extension programs. During the 1970s the value of mulch or residual dry matter (RDM) was recognized and incorporated into agency grazing guidelines when the UC Division of Agriculture and Natural Resources (UC DANR) published RDM guidelines. ${ }^{22,23}$ Synthesis studies of annual rangeland structure and function, supported by the International Biological Program, were incorporated into an annual grassland management short course. ${ }^{13,24}$ This course, repeated many times from 1979 to 2010, helped the state's rangeland managers understand the structure and function of annual rangeland ecosystems and practices that could be applied to effectively change species composition and productivity.

UC Cooperative Extension (UCCE) specialists and advisors were instrumental in supporting coordinated resource management planning (CRMP) as a way that agencies, universities, and public interest groups could attempt to find common ground where management of public lands could be addressed. In 1978 the Modoc/Washoe Experimental Stewardship Program was established as one of three CRMPs authorized by the Public Rangeland Improvement Act of 1978. UCCE county advisors and statewide specialists played an important enabling role in these efforts by providing the organizational skills, knowledge, and opportunity needed for individuals and groups of diverse backgrounds and conflicting positions to come together and address land management issues. These groups were among the first to highlight the need for assessment and monitoring to detect ecosystem change.

In the 1980s it was clear that UCCE needed to conduct education programs that helped land managers address the entire ranch or rangeland system rather than single improvement practices. Using ranch planning to integrate interdisciplinary and often competing objectives, an interdisciplinary team of extension specialists organized the first collaboration of UCCE specialists and farm advisors in natural resources management in 1982. This was the first of many collaborations that lead to the development of the UC DANR Integrated Hardwood Range Management Program (IHRMP) and the UC DANR Natural Resources Program Area. This was the leading edge of UCCE's effort to conduct environmental impact education programs for California landowners, managers, and policy makers. Starting in 1988 ranch management planning and grazing management short courses were developed and delivered locally to help ranchers document their resources, develop goals, and select practices to meet these goals. Monitoring procedures including RDM were demonstrated during these courses. These courses were conducted for nearly a decade but were replaced by short courses that would help ranchers cope with water quality issues.

In 1986 the IHRMP brought together researchers, educators, and managers in CDF, Department of Fish and Game, and UC to address oak regeneration issues. Researchers improved our knowledge of natural and management influences on regeneration and developed practices to improve oak regeneration, studied oak woodland habitat values, documented and classified oaks and oak woodlands, and investigated landowner attitudes about oaks and oak woodlands. ${ }^{25-28}$ Through frequent symposia and extension education programs directed at land use planners, landowners, and agency staff, the IHRMP effectively changed practices and attitudes about California's oak woodlands. ${ }^{29}$

In 1989 UCCE specialists and advisors in collaboration with the livestock industry, NRCS, and other agencies began addressing water quality issues and implemented the 
Rangeland Watershed Program, a program of extension education, technical assistance, and applied research..$^{30,31}$ In 1995 a UCCE Rangeland Watershed Specialist, Ken Tate, was hired and he initiated a multidisciplinary Cooperative Extension-Agricultural Experiment Station team that has successfully identified management strategies for minimizing transport of sediment and nutrients, minimizing microbial contamination of surface and ground water attributable to livestock production systems, and characterized stream temperature changes in grazed watersheds. ${ }^{32}$ From the beginning this extension and research program was focused on rangeland owners who collaborated by organizing education opportunities and providing access to their land and herds for many of the research projects in this program. More than 100 ranchers have provided their time, access to their land for water quality data collection, and access to their herds for sometimes invasive sampling procedures. One rancher, Russell Rustici, endowed three chairs in UCCE and the Agricultural Experiment Station at UC Davis and UC Berkeley and left a research and extension endowment of nearly $\$ 10$ million to the UC Davis College of Agriculture and Environmental Sciences to support livestock and rangeland research.

\section{Professional Service and Achievement}

UC researchers and educators have been very active participants in the profession of range management. UC participation in the Society for Range Management has led to invaluable collaborations with government agencies and opportunities to highlight UC range research. Drs Heady and Biswell were among the charter members of the Society for Range Management. Over the years more than 40 UC researchers and educators have served as section officers and some have been elected to national office. Additionally many have been recognized for their service to the profession receiving the Renner, Chapline, Fellow, Outstanding Achievement, and Outstanding Young Professional awards from SRM and Range Manager of the Year awards from the section.

\section{Acknowledgments}

Many of the publications included in Literature Cited have been archived at http://californiarangeland.ucdavis.edu/UC_ Range_-_Livestock_Publications/.

\section{Literature Cited}

1. Crocheron, R. H. 1914. The county farm advisors. Berkeley, CA, USA: University of California, College of Agriculture. Circular $112.12 \mathrm{p}$.

2. Crocheron, R. H. 1915. The county farm advisors. Berkeley, CA, USA: University of California, College of Agriculture. Circular $133.8 \mathrm{p}$.

3. Crocheron, R. H. 1917. The county farm bureau. Berkeley, CA, USA: University of California, College of Agriculture. Circular 166.12 p.
4. Kay, B. L., R. M. Love, and R. D. Slayback. 1981. Revegetation with native grasses. I. A disappointing history. Fremontia 8:11-15.

5. Adams, T. E. 1984. Fire fighting fire to manage California's brush rangelands. Rangelands 6:57-59.

6. Jones, B. J., And R. M. Love. 1945. Improving California ranges. Berkeley, CA, USA: California Agricultural Extension Service. Circular 129. 48 p.

7. Love, R. M., And B. J. Jones. 1947. Improving California brush ranges. Berkeley, CA, USA: California Agricultural Experiment Station. Circular 371. 31 p.

8. Williams, W. A., R. M. Love, And L. J. Berry. 1957. Production of range clovers. Berkeley, CA, USA: University of California Division of Agriculture. Circular 458. 19 p.

9. Murphy, A. H., M. B. Jones, J. W. Clawson, and J. E. Street. 1973. Management of clovers on California annual grasslands. Berkeley, CA, USA: University of California, Division of Agricultural Sciences. Circular 564. 19 p.

10. Phillips, D. A., And W. A. Williams. 1987. Range-legume inoculation and nitrogen fixation by root-nodule bacteria. Berkeley, CA, USA: University of California, Agricultural Experiment Station. Bulletin 1842 (formerly Bulletin 842). 13 p.

11. KAy, B. L. 1988. Long-term testing of range forage in Modoc County. Davis, CA, USA: University of California, Agronomy \& Range Science Department. Range Science Report 20.6 p.

12. Kay, B. L., C. M. Ross, and W. L. Graves. 1977. Mojave revegetation notes. Davis, CA, USA: Agronomy \& Range Science Department, University of California Davis. 205 p.

13. Jones, M. B., and R. G. Woodmansee. 1979. Biogeochemical cycling in annual grassland ecosystems. Botanical Review 45:111-144.

14. McKell, C. M., A. M. Wilson, and B. L. Kay. 1962. Effective burning of rangelands infested with medusahead. Weeds 10:125-131.

15. DiTomaso, J. M., G. B. Kyser, and M. J. Pitcairn. 2006. Yellow starthistle management guide. Berkeley, CA, USA: California Invasive Plant Council. Publication 2006-03. 78 p. Available at: http://www.cal-ipc.org/ip/management/yst.php. Accessed 10 July 2014.

16. Davy, J. S., J. M. DiTomaso, and E. A. Laca. 2008. Barb goatgrass. Oakland, CA, USA: University of California Division of Agriculture and Natural Resources. Publication 8315. 5 p.

17. Bentley, J. R., and M. W. Talbot. 1951. Efficient use of annual plants on cattle ranges in the California foothills. Washington, DC, USA: USDA. Circular $870.52 \mathrm{p}$.

18. Meadows, R. 2001. Hopland celebrates 50 years of rangeland research. California Agriculture 55(6):6-10. Available at: http://ucanr.org/repository/CAO/landingpage.cfm?article=ca. v055n06p6\&fulltext=yes. Accessed 10 July 2014.

19. Craigmill, A. L., and K. W.TAte. 2010. SFREC research sustains rangeland and oak woodlands (editorial). California Agriculture 64:54-56.

20. Meadows, R. 2010. Sierra Foothills Research Center celebrates 50 years of rangeland productivity. California Agriculture 64:5762. 
21. Parker, K. W., W. R. Chapline, L. W. Swift, G. W. Craddock, H. G. Reynolds, D. R. Cornelius, and H. H. Biswell. 1967. Arthur W. Sampson-pioneer range scientist. Journal of Range Management 20:346-352.

22. Clawson, W.J., N. K. McDougald, and D. A. Duncan. 1982. Guidelines for residue management on annual range. Berkeley, CA, USA: University of California, Division of Agriculture and Natural Resources. Publication 21327.

23. Bartolome, J. W., W. E. Frost, N. K. McDougald, and M. Connor. 2006. California guidelines for residual dry matter (RDM) management on coastal and foothill annual rangelands. Oakland, CA, USA: University of California, Division of Agriculture and Natural Resources. Publication 8092. 8 p.

24. Pendleton, D. F., J. W. Menke, W. A. Williams, and R. G. Woodmansee. 1983. Annual grassland ecosystem model. Hilgardia 51:1-44.

25. McCreary, D. D. 2001. Regenerating rangeland oaks in California. Oakland, CA, USA: University of California, Division of Agriculture and Natural Resources. Publication 21601. 62 p.

26. Block, W. M., M. L. Morrison, J. Verner, and P. N. Manley. 1994. Assessing wildlife-habitat-relationships models: a case study with California oak woodlands. Wildlife Society Bulletin 22:549-561.

27. Allen, B. H., B. A. Holzman, And R. R. Evett. 1991. A classification system for California's hardwood rangelands. Hilgardia 59:1-45.

28. Huntsinger, L., L. Buttolph, and P. Hopkinson. 1997. Ownership and management changes on California hard- wood rangelands: 1985 to 1992. Journal of Range Management 50:423-430.

29. Standiford, R. B., And J. Bartolome. 1997. The Integrated Hardwood Range Management Program: education and research as a conservation strategy. In: Proceedings of a Symposium on Oak Woodlands: Ecology, Management, and Urban Interface Issues; 19-22 March 1996; San Luis Obispo, CA, USA. USDA Forest Service. Research Paper PSW-GTR-160. p. 569-581.

30. Larson, S., K. Smith, D. Lewis, J. Harper, and M. George. 2005. Evaluation of California's Rangeland Water Quality Education Program. Rangeland Ecology \& Management 58:514-522.

31. George, M. R., S. Larson-Praplan, J. Harper, D. Lewis, And M. Lennox. 2011. California's Rangeland Water Quality Management Plan: an update. Rangelands 33:20-24.

32. Dahlgren, R. A., K. W. Tate, D. J. Lewis, E. R. Atwill, J. M. Harper, and B. H. Allen-Diaz. 2001. Watershed research examines rangeland management effects on water quality. California Agriculture 55(6):64-71.

Authors are Extension Rangeland Management Specialists, Emeritus, Plant Sciences Department, University of California, Davis, CA 95616, USA (mrgeorge@ucdavis.edu). A longer version of this article was published by University of California Agriculture and Natural Resources and is available at http:// californiarangeland.ucdavis.edu/files/190478.pdf. 